\title{
Long-term database of Beasley Lake Watershed with 25 years of agricultural conservation practices
}

\author{
Richard Lizotte $^{1}$, Lindsey Yasarer $^{1}$, Mark Griffith $^{1}$, Martin Locke $^{1}$, and Ronald Bingner ${ }^{1}$ \\ ${ }^{1}$ USDA-ARS National Sedimentation Laboratory
}

September 22, 2020

\begin{abstract}
Beasley Lake Watershed is an agriculturally influenced drainage basin in western Mississippi that has been intensively studied for 25 years. As part of the USDA Conservation Effects Assessment Project (CEAP), the watershed has archived hydrology, precipitation, and water quality data in order to measure the effects of multiple USDA Natural Resources Conservation Service conservation practices on lake water quality. The long-term database is available to researchers using a web-based application, Sustaining the Earth's Watersheds, Agricultural Research Data System (STEWARDS). STEWARDS is a GIS-based data retrieval application that encompasses spatial and temporal data collected from multiple sites within the watershed. This data note describes information located in the STEWARDS Beasley Lake Watershed database, including hydrology, precipitation, and water quality data. This information is valuable to researchers and agencies beyond the USDA as an available and useful database to improve the understanding of how land-use practices affect the water quality of shallow lake systems.
\end{abstract}

Long-term database of Beasley Lake Watershed with 25 years of agricultural conservation practices

Richard E. Lizotte, Jr. ${ }^{1}$, Lindsey M. W. Yasarer ${ }^{1}$, Mark K. Griffith ${ }^{1}$, Martin A. Locke ${ }^{1}$, and Ronald L. Bingner ${ }^{1}$

${ }^{1}$ USDA-ARS National Sedimentation Laboratory, Oxford, Mississippi 38655, USA

Abstract

Beasley Lake Watershed is an agriculturally influenced drainage basin in western Mississippi that has been intensively studied for 25 years. As part of the USDA Conservation Effects Assessment Project (CEAP), the watershed has archived hydrology, precipitation, and water quality data in order to measure the effects of multiple USDA Natural Resources Conservation Service conservation practices on lake water quality. The long-term database is available to researchers using a web-based application, Sustaining the Earth's Watersheds, Agricultural Research Data System (STEWARDS). STEWARDS is a GIS-based data retrieval application that encompasses spatial and temporal data collected from multiple sites within the watershed. This data note describes information located in the STEWARDS Beasley Lake Watershed database, including hydrology, precipitation, and water quality data. This information is valuable to researchers and agencies beyond the USDA as an available and useful database to improve the understanding of how land-use practices affect the water quality of shallow lake systems.

1 Site Description and Methods

Beasley Lake Watershed, located in Sunflower County, Mississippi, USA (Latitude 33.398336; Longitude 90.676390), has a total drainage area of approximately 625 ha including a large riparian forested wetland (125 ha; Figure 1). The catchment is part of the Big Sunflower River drainage basin (United States Geological Survey Hydrologic Unit Code 08030207). Beasley Lake is a 25-ha isolated meander channel (oxbow lake) of the river. Bathymetric measurements of lake geometry were taken in July 2020 using a Garmin ECHOMAP 
Plus 93sv unit, processed with Sonar TRX software, and analyzed with ArcMap to generate lake surface area and volume estimates (Figure 2). Watershed relief from the top of the watershed boundary to the lake surface is about $5.5 \mathrm{~m}$ and watershed soil texture varies from sandy loam to heavy clay (see: Lizotte et al. 2017; Locke et al. 2020).

Approximately $53-70 \%$ of the watershed has been farmed as row cropland over the study period (19952019 ), with prominent crop types including cotton (70\% of cropped area 1995-2001), corn, and soybean (75\% cropped area 2002-2019). Established structural conservation practices were vegetated buffers (VBS, 19952001, 2006), set-asides (Conservation Reserve CRP, 2003), a constructed wetland (WET, 2002), and sediment retention pond (SRP, 2010) (Locke et al. 2020). The annual areas of conservation practices and crop types are listed in Table 1 . Biweekly lake depth was measured when taking water quality samples in the lake with a calibrated depth line. Precipitation measurements within the watershed are measured at the USDA Soil Climate Analysis Network (SCAN) climate station (ID 2032: latitude 33.38; longitude -90.65). Biweekly lake water samples were collected $10 \mathrm{~cm}$ below the water surface at three sites: east end of the lake (Site 1), mid-point (Site 2), and west end (Site 3). In Situ dissolved oxygen, $\mathrm{pH}$, temperature, and conductivity were measured with a Yellow Springs Instruments handheld sonde $10 \mathrm{~cm}$ below the water surface, in addition to Secchi depth visibility. Laboratory-measured parameters are: total suspended solids, total dissolved solids, turbidity, filtered orthophosphate, total phosphorus (TP), ammonium-nitrogen, nitrate-nitrogen, nitritenitrogen, total Kjeldahl nitrogen and chlorophyll $a$. Details about laboratory analysis techniques and quality control procedures are found in the STEWARDS database as well as in Lizotte et al. (2017) and Locke et al. (2020).

2 Results

Water quality conditions in the lake have generally improved over time (Lizotte et al. 2014, 2017), with notable improvements after establishment of multiple structural conservation practices. Additional improvement in water quality, specifically for TP, was evident after the installation of SRP in 2010 (Figure 3). Higher TP $\left(75^{\text {th }}-95^{\text {th }}\right.$ percentiles) showed decreasing concentrations after established VBS (1995-2001) and further decreasing TP after established WET, CRP, QB, and SRP (2002-2016). After 2010, highest TP concentration did not exceed $1 \mathrm{mg} / \mathrm{L}$ in any sample and rarely exceeded $0.5 \mathrm{mg} / \mathrm{L}(13 \%$ in $2011 ;<3 \%$ in 2018). Total phosphorus data demonstrate not only improvements in TP, but also the effect of lag-times for conservations practices, especially SRP (Figure 3).

As a typical oxbow lake, the basin shape mirrors the historic riverbed with a flat bottom, steep sides, and gradual depth transitions at the top and bottom of the lake. Bathymetric measurements found a 3D lake bottom surface area of $239,000 \mathrm{~m}^{2}$ and a lake volume of $216,000 \mathrm{~m}^{3}$ at a maximum depth of $2.58 \mathrm{~m}$. Lake depth varied between 1.58 and $4.83 \mathrm{~m}$ over the time period of this study; therefore, the lake volume estimated here represents normal conditions. Under high flow conditions, the edge of the lake extends up through dense vegetation to reach an outlet pipe that then overflows into the Big Sunflower River. This area is not navigable by boat, and therefore was not included in the bathymetric measurements. The estimated area of this top lake extension is $46,000 \mathrm{~m}^{2}$. Similarly, the lake often floods into a non-navigable riparian wetland extension within the forested section of the watershed. The estimated area of this riparian wetland extension is $138,000 \mathrm{~m}^{2}$. Water level in both areas is estimated to be less than $1 \mathrm{~m}$ under normal conditions.

Data availability

Data described in this note are available at the US Department of Agriculture-Agricultural Research Service (USDA-ARS), STEWARDS v3.0: Access to ARS CEAP Benchmark Watershed Data (Sadler et al. 2020). Data are continuously updated to add additional years of data as they are quality controlled and corrected. https://www.nrrig.mwa.ars.usda.gov/stewards/stewards.html

Acknowledgements

Disclaimer: The use of trade, firm, or corporation names is solely for the information and convenience of the reader. Mention of names does not constitute an official endorsement or approval by the USDA or the 
Agricultural Research Service of any product or service to the exclusion of others that may be suitable. The USDA prohibits any discrimination in all its programs and activities on the basis of race, color, national origin, age, disability, sex, marital status, familial status, parental status, religion, sexual orientation, genetic information, political beliefs, reprisal, or because any part of an individual's income is derived from any public assistance program.

\section{References}

Lizotte, R., Knight, S., Locke, M., \& Bingner, R. (2014). Influence of integrated watershed-scale agricultural conservation practices on lake water quality. Journal of Soil and Water Conservation 69, 160-170. doi:10.2489/jswc.69.2.160

Lizotte, R., Yasarer, L., Locke, M., Bingner, R., \& Knight, S. (2017). Lake nutrient responses to integrated conservation practices in an agricultural watershed. Journal of Environmental Qualit y 46, 330-338. doi:10.2134/jeq2016.08.0324

Locke, M., Lizotte, R., Yasarer, L., Bingner, R., \& Moore, M. (2020). Surface runoff in Beasley Lake watershed: Effect of land management practices in a Lower Mississippi River Basin watershed. Journal of Soil and Water Conservation 75, 278-290. doi:10.2489/jswc.75.3.278.

Sadler, E., Steiner, J., Hatfield, J., James, D., Vandenberg, B., \& Tsegaye, T. (2020). STEWARDS: A decade of increasing the impact of Agricultural Research Service watershed research programs. Journal of Soil and Water Conservation 75, 50A-56A. doi:10.2489/jswc.75.3.50A

Figure Legend

Figure 1. Beasley Lake Watershed delineation and land use

Figure 2. Beasley Lake bathymetric map

Figure 3. Annual box plots of total phosphorus in Beasley Lake surface water from 1995-2019.

\section{Hosted file}

Hydrological Processes Special Issue Data Note Lizotte et al TABLE 1.pdf available at https://authorea.com/users/360925/articles/482469-long-term-database-of-beasley-lakewatershed-with-25-years-of-agricultural-conservation-practices

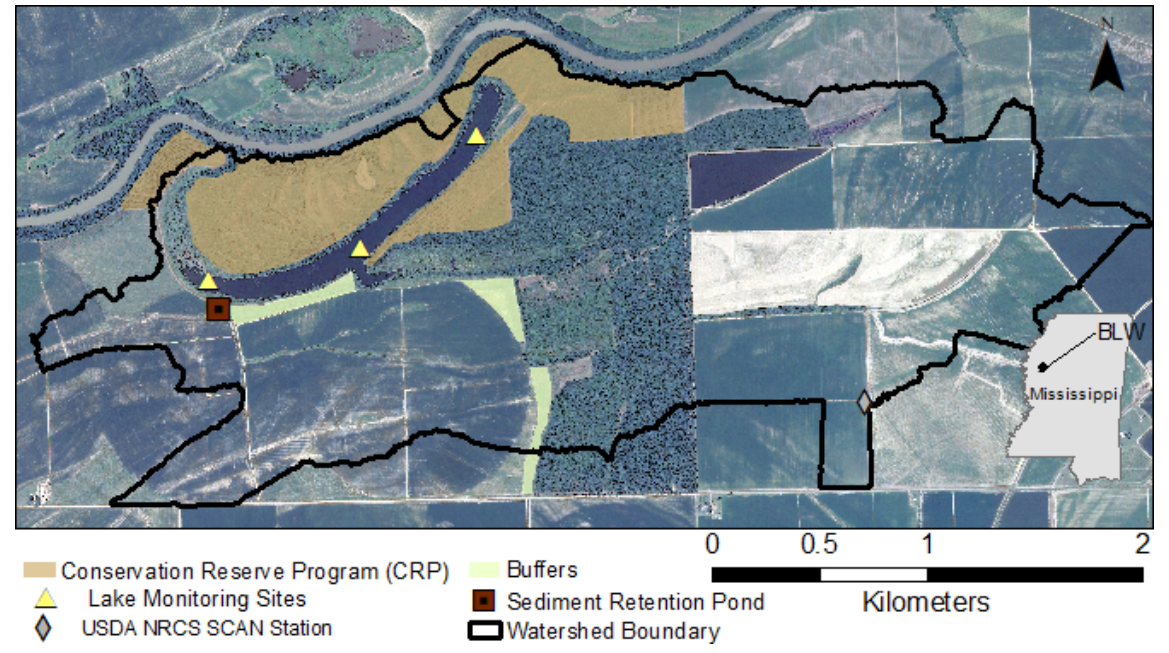



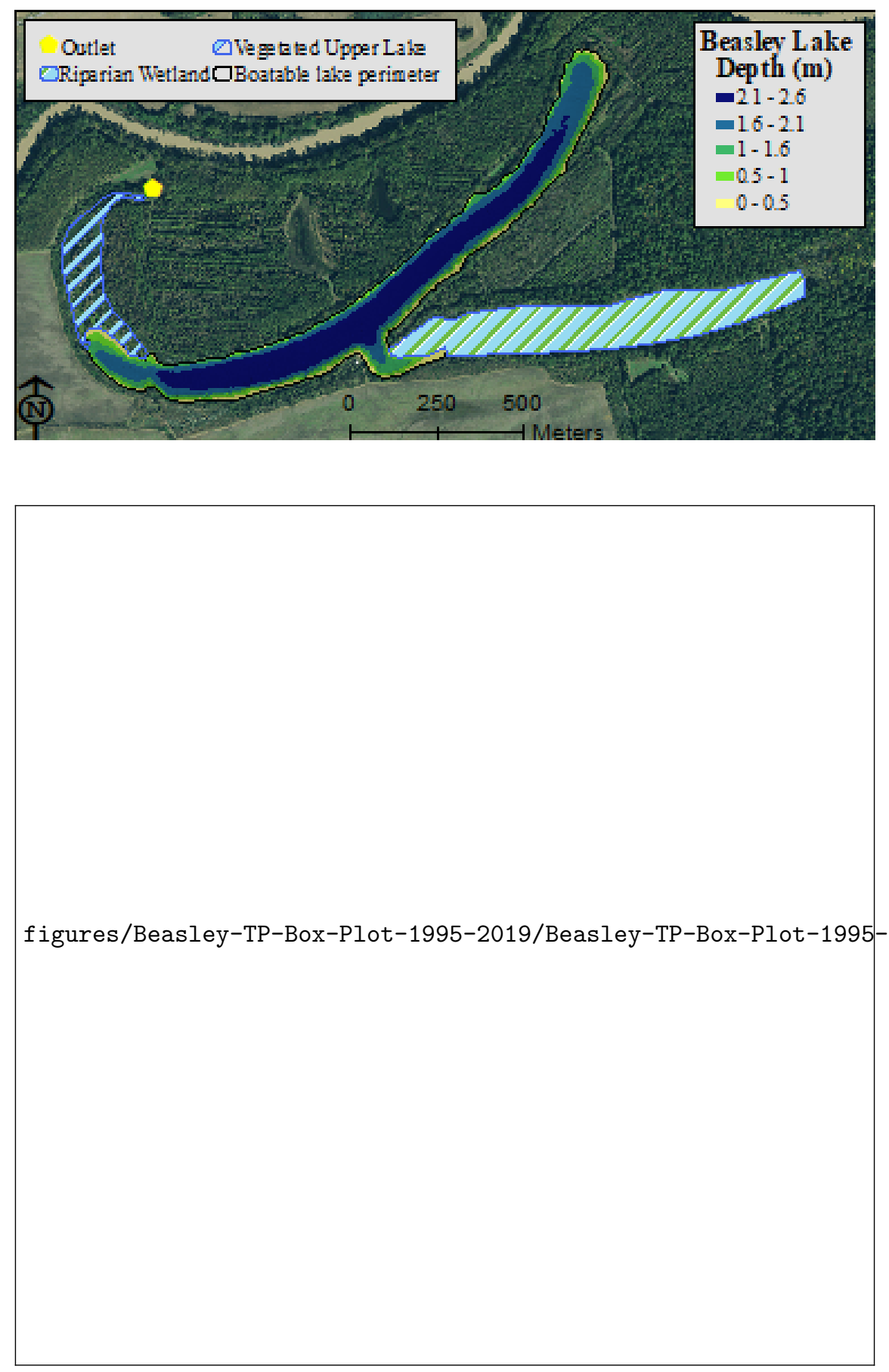